Analytica Chimica Acta, 63 (1973) 185-196

185

(C) Elsevier Scientific Publishing Company, Amsterdam - Printed in The Netherlands

\title{
ACID-BASE STRENGTHS IN 1,2-DICHLOROETHANE
}

M. BOS and E. A. M. F. DAHMEN

Department of Chemical Technology, Twente University of Technology, Enschede (The Netherlands)

(Received 11th July 1972)

1,2-Dichloroethane can be used successfully as a solvent in acid-base titrations ${ }^{1}$. The dielectric constant of dichloroethane is 10.60 at $20^{\circ 2}$, which is almost the same as that of pyridine or $m$-cresol.

Comparison of the $\mathrm{p} K_{\mathrm{a}}$ values determined in dichloroethane with the $\mathrm{p} K_{\mathrm{a}}$ values of the same compounds in $m$-cresol ${ }^{3}$ and pyridine ${ }^{4,5}$ thus shows the influence of the basicity of these solvents on acid strengths. Owing to the low dielectric constant, ion-pair formation has to be considered in describing the titrations. Moreover, as dichloroethane has a low solvating power, the occurrence of hydrogenbonded complexes has also to be taken into account. The $p K_{\mathrm{a}}$ values of various compounds in dichloroethane can be determined from potentiometric titrations that are carried out with a calibrated glass electrode.

The glass electrode can be calibrated by means of an acid with a dissociation constant known from conductometric experiments. Ion-pair dissociation constants of salts can also be found from conductometric determinations.

\section{EXPERIMENTAL}

\section{Chemicals}

1,2-Dichloroethane (Merck, "zur Synthese") was dried for at least $48 \mathrm{~h}$ on molecular sieve $3 \AA$ (Union Carbide) before use. The water content of this solvent was always below $0.005 \%$ (Karl Fischer titration). The sulfonphthaleins (Merck, indica tor grade) were used as received. Tetramethylguanidinium iodide was prepared by bubbling dry hydrogen iodide (Baker) through a solution of tetramethylguanidine in alcohol. The salt was recrystallized twice from alcohol/ether and dried at $40^{\circ}$ in vacuo. Trifluoromethanesulfonic acid (Eastman Kodak) was used as received.

Other chemicals were as described earlier ${ }^{3}$.

\section{Apparatus and procedures}

In the potentiometric titrations a Radiometer automatic titration assembly was used. This assembly consisted of: glass electrode $\mathrm{G} 2222 \mathrm{C}, \mathrm{Ag} / \mathrm{AgCl}$ reference electrode filled with a saturated solution of tetramethylammonium chloride in dichloroethane, pH-meter PHM26, titrator TT111, burette ABU12 and recorder SBRc. The glass electrode was stored in aqueous buffer $\mathrm{pH} 7$ when not in use. Before starting the titrations, the electrode set was equilibrated for $5 \mathrm{~min}$ in the solution to be titrated. During titrations the solution was thermostatted at $20^{\circ} \pm 0.1$. Titration curves were reproducible within $\pm 5 \mathrm{mV}$. The electrode set was recalibrated every 
day in a buffer solution containing $0.04 M$ picric acid and $0.04 M$ tetramethylguanidinium picrate in dichloroethane.

The conductometric experiments were carried out at $20 \pm 0.1^{\circ}$ with the use of a Radiometer conducitivity cell, type CDC114, and a conductometer bridge ("Wissenschaftliche Technische Werkstätten", type LBR). With freshly prepared potassium chloride solutions, the cell constant was found to be $0.534 \mathrm{~cm}$.

To prevent moisture influence on the conductivities, a glove box in which the humidity was below 30 p.p.m. was used in the experiments.

\section{THEORY}

The dissociation constants of salts can be determined conductimetrically by the method of Fuoss and Kraus ${ }^{6,7}$. For very weak acids the dissociation constants cannot be calculated directly from conductivity measurements, because the extrapolation to find $\Lambda_{0}$, the equivalent conductance at infinite dilution, cannot be performed. In dichloroethane, because of its low basicity, all acids are very weak and therefore it is impossible to find the acid dissociation constants directly from conductivity measurements. With the use of Walden's ${ }^{8}$ rule, which states that the product of the equivalent conductance at infinite dilution and the viscosity of the solvent is a constant for a given electrolyte going from one solvent to another, one can calculate $\Lambda_{0}$ in dichloroethane from $\Lambda_{0}$ in another solvent for the same electrolyte and use this value in the computation of the dissociation constant.

In the determination of $\mathrm{p} K_{\mathrm{u}}$ values from potentiometric titration curves in dichloroethane, the appropriate set of equilibria can be chosen and the equilibrium constants estimated and adjusted until the experimental curve and the titration curve calculated with the computer program EQUIL ${ }^{9}$ coincide.

The basic set of equilibria that can be used to explain the titration data consists of the following equilibria:

$$
\begin{aligned}
& \mathrm{HX} \leftrightharpoons \mathrm{H}^{+}+\mathrm{X}^{-} \\
& \mathrm{B}+\mathrm{H}^{+} \leftrightharpoons \mathrm{BH}^{+} \\
& \mathrm{BH}^{+}+\mathrm{X}^{-} \leftrightharpoons \mathrm{BHX}
\end{aligned}
$$

On the acidic side of the equivalence point the titration curve is completely determined by equilibria (1) and (3), and on the alkaline side by equilibria (2) and (3). Therefore, if one equilibrium constant is known, the other equilibrium constants can be determined from the different parts of the titration curve. Because of the low solvating power of dichloroethane, additional equilibria have to be taken into account in many instances.

\section{Carboxylic acids}

In the titration of carboxylic acids with tetramethylguanidine (TMG) in dichloroethane, dimerization of these acids occurs:

$$
2 \mathrm{HX} \leftrightharpoons(\mathrm{HX})_{2}
$$

Dimerization constants can be determined by differential vapour pressure osmometry on solutions of the acids. The titration curves of these acids show an inflection at 
half neutralization. In order to explain this the equilibrium

$$
\mathrm{BHX}+\mathrm{HX} \leftrightharpoons \mathrm{B}(\mathrm{HX})_{2}
$$

must be assumed.

\section{Hydrogen halides}

The titration curves of hydrogen halides with TMG show before the equivalence point a larger increase in $\mathrm{pH}$ value than can be explained by the equilibria (1), (2) and (3). This shape of the titration curve can also be explained by the occurrence of the complex $\mathbf{B}(\mathrm{HX})_{2}$ as in equilibrium (5).

\section{Sulfonphthaleins}

The behaviour of the dibasic sulfonphthaleins during titration can be described by the following equilibria:

$$
\begin{aligned}
& \mathrm{H}_{2} \mathrm{X} \leftrightharpoons \mathrm{H}^{+}+\mathrm{HX}^{-} \\
& \mathrm{HX}^{-} \leftrightharpoons \mathrm{H}^{+}+\mathrm{X}^{2-} \\
& \mathrm{B}+\mathrm{H}^{+} \leftrightharpoons \mathrm{BH}^{+} \\
& \mathrm{BH}^{+}+\mathrm{HX}^{-} \leftrightharpoons \mathrm{BH}_{2} \mathrm{X} \\
& \mathrm{BH}^{+}+\mathrm{X}^{2-} \leftrightharpoons \mathrm{BHX}^{-} \\
& \mathrm{BH}^{+}+\mathrm{BHX}^{-} \leftrightharpoons \mathrm{B}_{2} \mathrm{H}_{2} \mathrm{X}
\end{aligned}
$$

The separate equilibrium constants (6)-(11) only affect certain parts of the titration curve. This makes it possible to determine these equilibrium constants from the titration curve when only a few of them are known to start with. If the equilibrium constant (8) is known, the procedure to find the others from the titration curve is as follows. The titration curve is divided into four regions (see Fig. 1), each region giving the possibility of determining one dissociation constant:

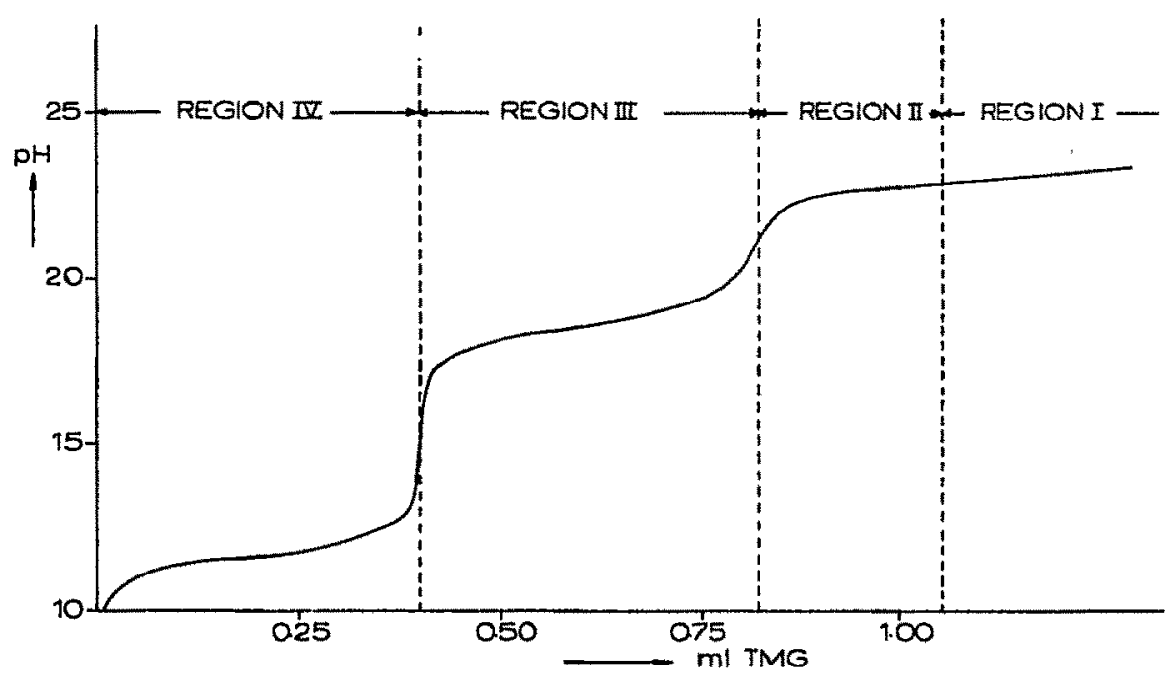

Fig. 1. Titration of $3 \mathrm{ml}$ of $0.01140 \mathrm{M}$ bromocresol green with $0.0855 \mathrm{M} \mathrm{TM}$ in 1,2-dichloroethane. 
Region I: more than $30 \%$ after the second equivalence point. Here the titration curve is determined by the constants of equilibria (8) and (11), $K_{8}$ and $K_{11}$, respectively. $K_{8}$ is known, so $K_{11}$ can be found.

Region II: just after the second equivalence point. This part of the titration curve is influenced by $K_{8}, K_{11}$ and $K_{10}$. With known values for $K_{8}$ and $K_{11}, K_{10}$ can be calculated.

Region III: from the first to the second equivalence point. $K_{7}, K_{9}, K_{10}$ and $K_{11}$ determine the titration curve. Only $K_{10}$ and $K_{11}$ are known at this stage of the calculation, so only combinations of $K_{7}$ and $K_{9}$ can be found. If it is assumed that $K_{9}=K_{11}$, then $K_{7}$ can be found separately.

Region IV: from the start of the titration curve to the first equivalence point. The titration curve is fixed by $K_{6}$ and $K_{9}$. If $K_{9}$ is known, $K_{6}$ can be calculated. RESULTS

Conductometric determination of TMG salt dissociation constants

Salt dissociation constants in dichloroethane were determined by the method of Fuoss and Kraus ${ }^{6,7}$ from conductivity measurements on dilution series of the salts in dichloroethane. The results are given in Table I.

TABLE 1

DISSOCIATION CONSTANTS OF TMG SALTS IN DICHLOROETHANE AT $20^{\circ}$ FROM CONDUCTIVITY MEASUREMENTS

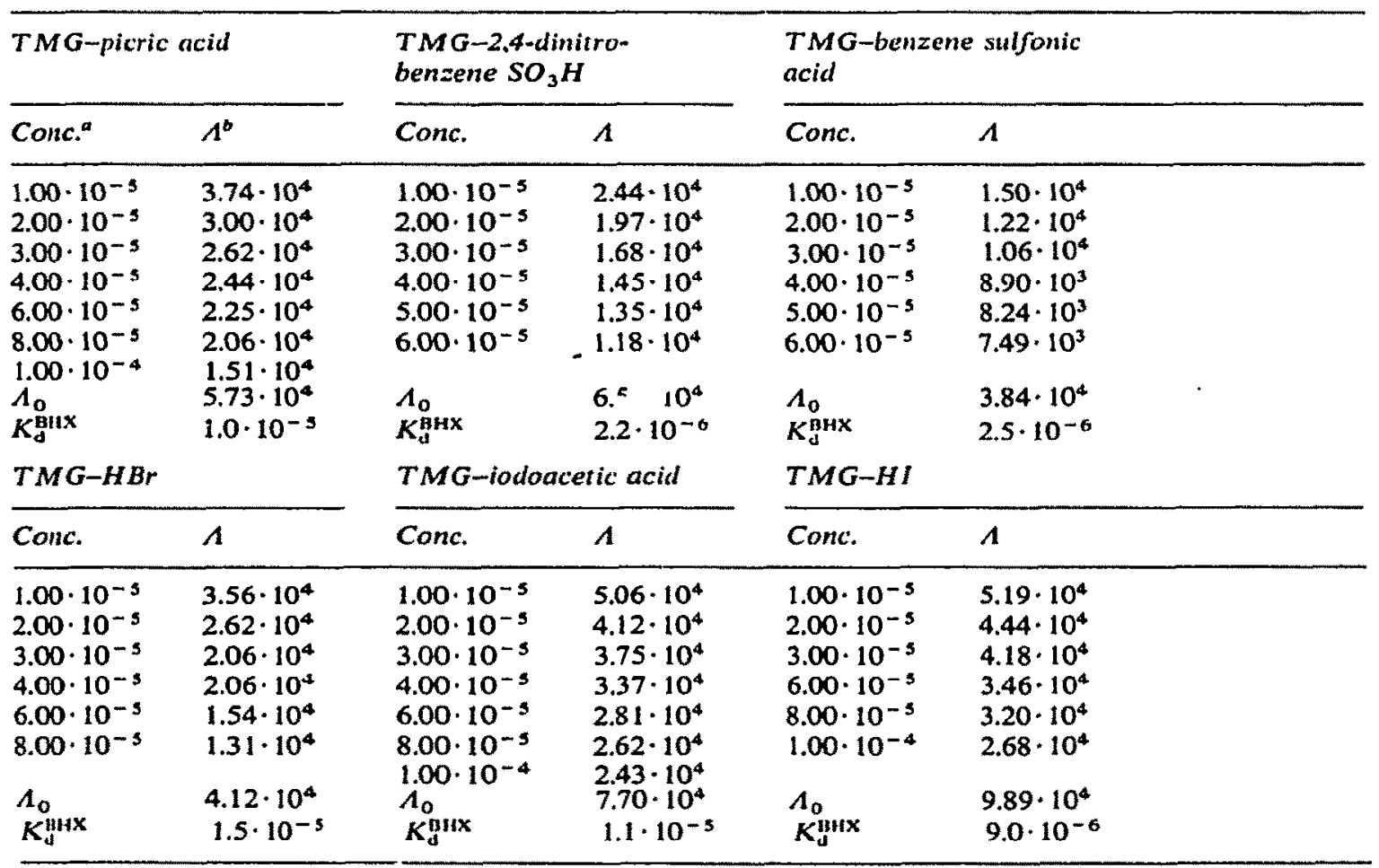

- In mol $1^{-1}$.

In ohm-1 $\mathrm{cm}^{2} \mathrm{eq}^{-1}, 10^{2}$. 
Dissociation of hydriodic acid

The dissociation constant of hydriodic acid in dichloroethane was determined conductometrically. The equivalent conductance $\Lambda_{0}$ of hydriodic acid in dichloroethane at infinite dilution, necessary in the calculations, was estimated from the $\Lambda_{0}$ value of hydriodic acid in $m$-cresol ${ }^{3}$ by Walden's ${ }^{8}$ rule.

This rule was checked for these two solvents by means of the data obtained for the TMG salts (Table II).

On average the calculated $A_{0}$ values in dichloroethane are a factor of 2 higher than the values determined conductometrically. Therefore the value $6.7 \cdot 10^{4}$ for $\Lambda_{0}$ of hydriodic acid in dichloroethane was used in the calculation of its dissociation constant from the conductance data. The result is given in Table III.

TABLE II

WALDEN'S RULE FOR m-CRESOL AND DICHLOROE'THANE

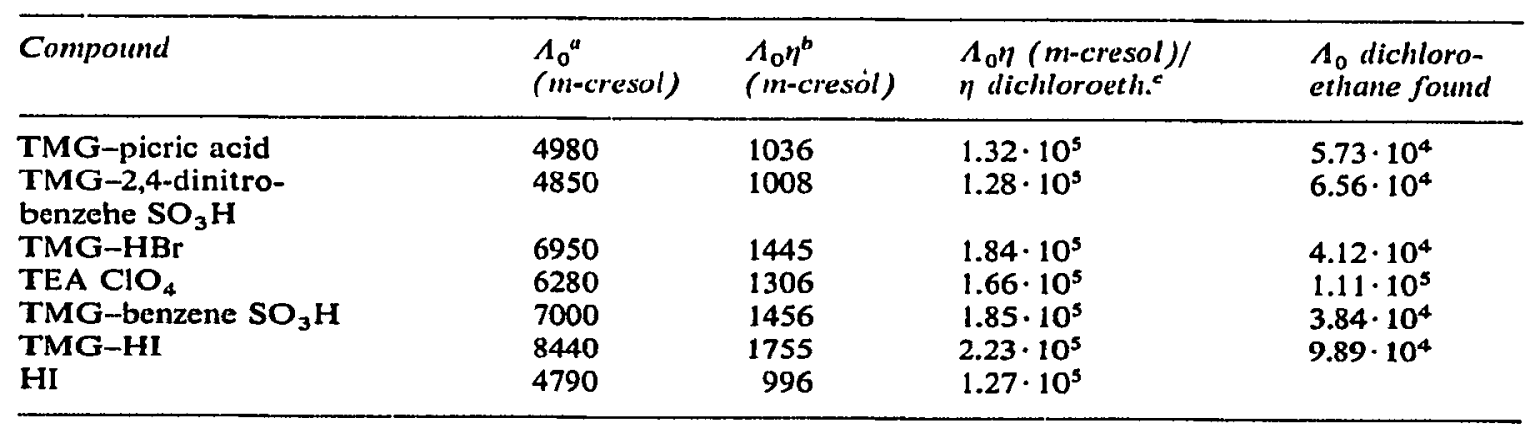

"In $\mathrm{ohm}^{-1} \mathrm{~cm}^{2} \mathrm{eq}^{-1} \cdot 10^{3}$.

$b$ Viscosity of $m$-cresol, 0.208 P.

- Viscosity of dichloroethane, $0.00787 \mathrm{P}$.

TABLE III

DISSOCIATION CONSTANT OF HYDRIODIC ACID IN DICHLOROETHANE FROM CONDUCTIVITY MEASUREMENTS

\begin{tabular}{lll}
\hline $\begin{array}{l}\text { Conc. } \\
(\text { mol l }\end{array}$ & $\begin{array}{l}\text { A }) \\
\left(\mathrm{ohm}^{-1} \mathrm{~cm}^{2} e \mathrm{q}^{-1} \cdot \mathrm{lo}\right)\end{array}$ & $\begin{array}{l}K_{\mathrm{HI}} \\
\left(\mathrm{mol} \mathrm{l} \mathrm{l}^{-1}\right)\end{array}$ \\
\hline 0.00205 & 146 & $9.7 \cdot 10^{-9}$ \\
0.00410 & 129 & $1.5 \cdot 10^{-8}$ \\
0.00614 & 98.7 & $1.3 \cdot 10^{-8}$ \\
0.00819 & 87.1 & $1.4 \cdot 10^{-8}$ \\
0.0123 & 82.2 & $1.8 \cdot 10^{-8}$ \\
0.0164 & 75.0 & $2.0 \cdot 10^{-8}$ \\
0.0205 & 60.5 & $1.7 \cdot 10^{-8}$ \\
& & Mean value of $K_{\mathbf{l I I}} 1.4 \cdot 10^{-8}$ \\
\hline
\end{tabular}

Calibration of the glass electrode

The glass electrode was calibrated in the potentiometric titration of hydriodic acid with tetramethylguanidine. This titration can be described by means of the 


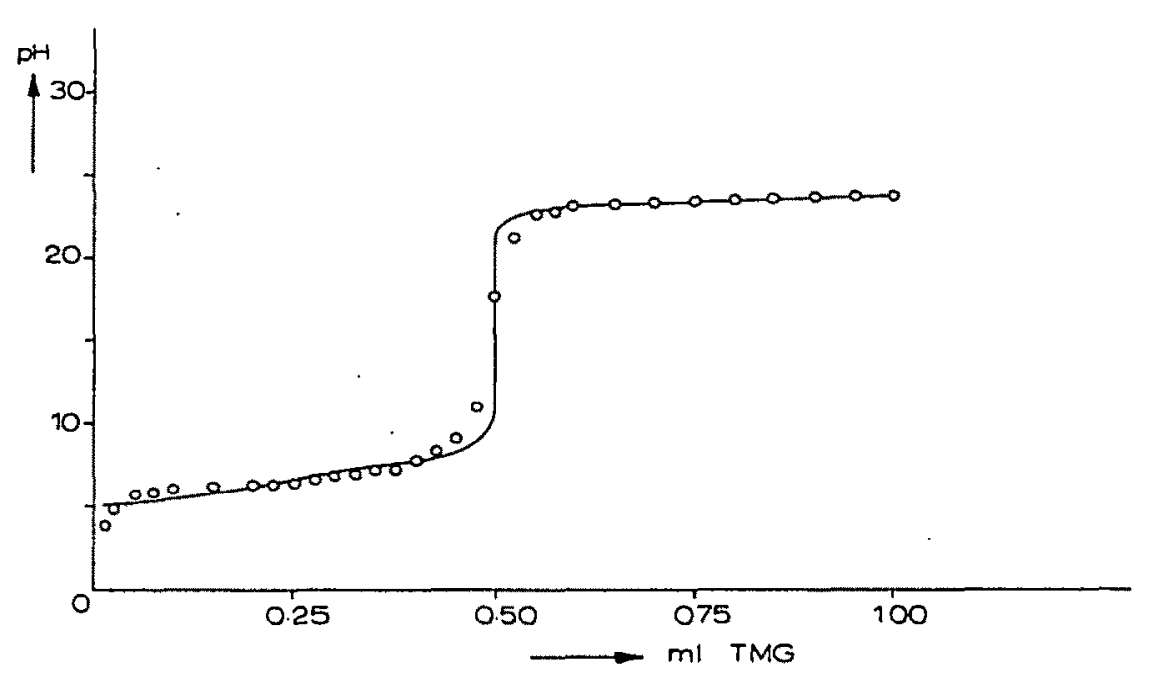

Fig. 2. Titration of $3.5 \mathrm{ml}$ of $0.01644 M$ hydriodic acid with $0.1168 M \mathrm{TMG}$ in dichloroethane.

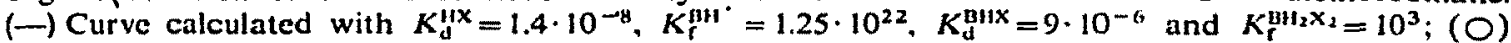
exp. calculated with $E_{0}=1208 \mathrm{mV}$.

equilibria (1), (2), (3) and (5). The first part of the titration curve (Fig. 2) is completely determined by the equilibria (1), (3) and (5). From the results of conductometric measurements the equilibrium constants (1) and (3) are known to be $1.4 \cdot 10^{-8}$ and $1 / 9.0 \cdot 10^{-6}$, respectively. Equilibrium constant (5) was found to be 1000 from an estimated value which was adjusted until the shape of the calculated curve was the same as that of the experimental one. With the use of the formula

$$
E_{\mathrm{mv}}=E_{\mathrm{omv}}-59 \mathrm{pH}
$$

for its behaviour, the glass electrode was calibrated by calculating $E_{0}$ from the recorded $E$ values and the computed $\mathrm{pH}$ values of the titration curve. The result is given in Table IV.

\section{Dimerization of iodoacetic acid}

The dimerization constant of iodoacetic acid was determined by means of differential vapour pressure osmometry as described by Coetzee and Lok ${ }^{10}$. The result is given in Table $\mathrm{V}$.

Dissociation constants from potentiometric titrations with the calibrated glass electrode

With the use of the procedure outlined under Theory, dissociation constants of acids, protonated nitrogen bases and salts were found from the curves of potentiometric titrations with the calibrated glass electrode.

In the calculations of the titrations of hydriodic acid, picric acid, hydrobromic acid, iodoacetic acid and benzoic acid, the conductometric salt dissociation constants were used. For iodoacetic acid the dimerization constant from osmometry was used, while for benzoic acid the value 87 for this constant was taken from the literature ${ }^{10}$. From these calculations the $\mathrm{p} K_{\mathrm{a}}$ values of the acids and the tetramethylguanidinium ion were found. This dissociation constant of tetramethylguanidinium 
TABLE IV

CALIBRATION OF THE GLASS ELECTRODE IN THE TITRATION OF $3.500 \mathrm{ml}$ OF $0.01644 M$ HYDRIODIC ACID WITH $0.1168 M$ TMG

\begin{tabular}{llll}
\hline $\begin{array}{l}m \text { T TMG } \\
\text { added }\end{array}$ & $\begin{array}{l}p H \\
\text { calculated }\end{array}$ & $\begin{array}{l}m V \\
\text { found }\end{array}$ & $\begin{array}{l}E_{\mathrm{o}} \\
(\mathrm{mV})\end{array}$ \\
\hline 0.025 & 5.17 & 914 & 1219 \\
0.050 & 5.30 & 869 & 1182 \\
0.075 & 5.43 & 864 & 1184 \\
0.100 & 5.56 & 849 & 1177 \\
0.150 & 5.85 & 844 & 1199 \\
0.200 & 6.20 & 839 & 1215 \\
0.225 & 6.40 & 834 & 1212 \\
0.250 & 6.61 & 829 & 1219 \\
0.275 & 6.83 & 814 & 1217 \\
0.300 & 7.04 & 804 & 1219 \\
0.325 & 7.24 & 799 & 1226 \\
0.350 & 7.43 & 784 & 1222 \\
$0.362^{5}$ & 7.53 & 779 & 1223 \\
0.375 & 7.63 & 769 & 1219 \\
0.400 & 7.82 & 749 & 1210 \\
$0.412^{5}$ & 7.93 & 734 & 1202 \\
& & & \\
& Average value of $E_{0}=1208 \mathrm{mV}$ \\
\hline
\end{tabular}

TABLE V

DIMERIZATION OF IODOACETIC ACID IN DICHLOROETHANE AT $37^{\circ}$

\begin{tabular}{lll}
\hline Conc. stoich." & Conc. osin. & $K_{\mathrm{dim}}{ }^{\mathrm{c}}$ \\
\hline 0.020 & 0.0150 & 53 \\
0.030 & 0.0215 & 50 \\
0.040 & 0.0280 & 47 \\
0.060 & 0.0399 & 51 \\
0.070 & 0.0462 & 47 \\
0.080 & 0.0511 & 58 \\
0.090 & 0.0574 & 53 \\
0.100 & 0.0641 & 45 \\
& Average value $K_{\text {dim }} 51$ \\
\hline
\end{tabular}

a Stoichiometric concentration of iodoacetic acid in $\mathrm{mol}^{-1}$

- Molar concentration from osmometry.

- In $\mathrm{mol}^{-1} \mathrm{l}$.

ion was used in the other TMG titrations to produce $\mathrm{p} K_{\mathrm{a}}$ values for sulfonphthaleins, benzenesulfonic acid and hydrochloric acid, and the dissociation constants of their TMG salts. From the titration of $n$-butylamine with hydriodic acid, the dissociation constant of protonated $n$-butylamine and its hydriodic acid salt was found.

In the titrations with trifluoromethanesulfonic acid, salt dissociation constants were assumed to have the value $10^{-5}$ to obtain the $\mathrm{p} K_{\mathrm{a}}$ values of the protonated 


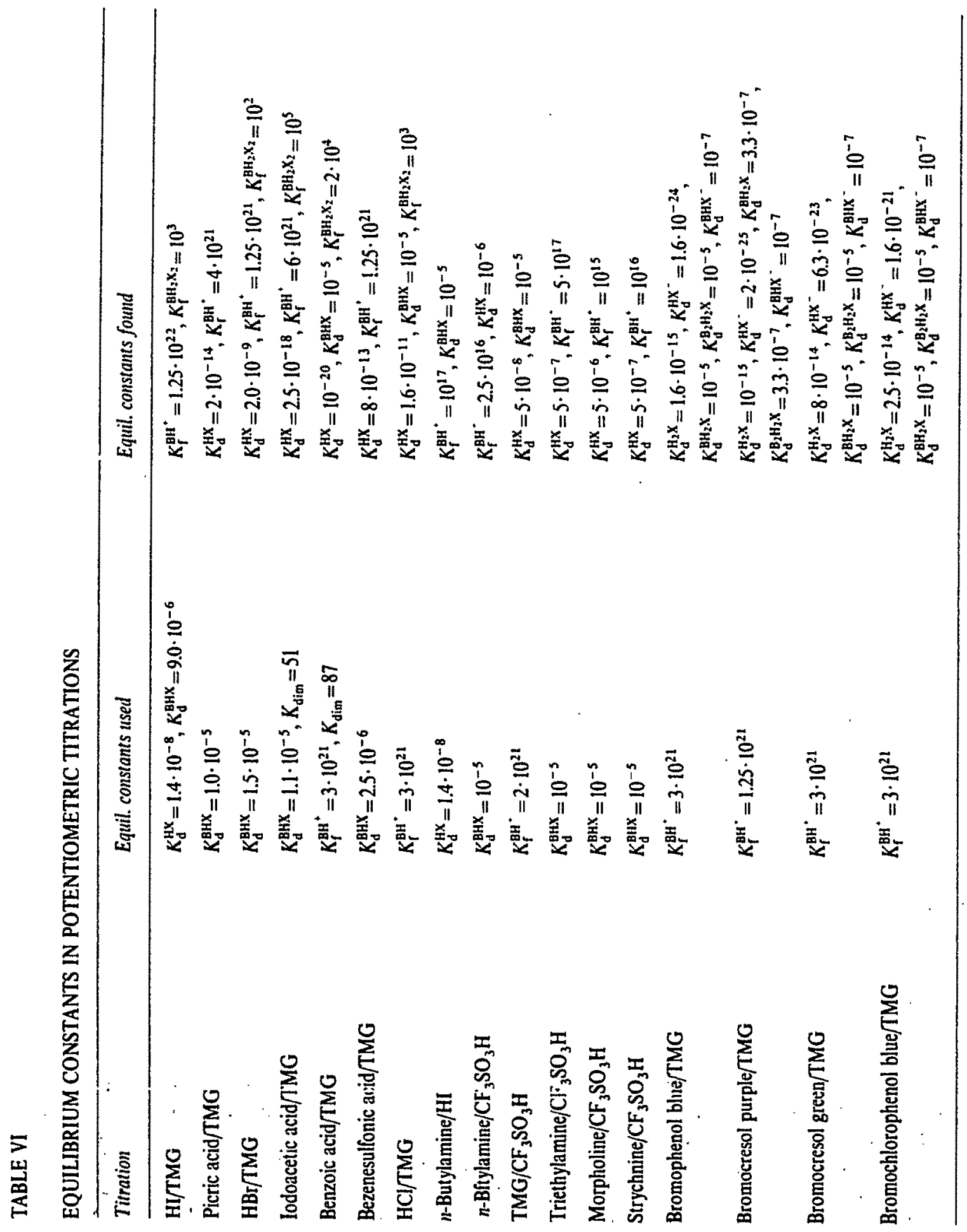


nitrogen bases $n$-butylamine; triethylamine, morpholine and strychnine. The data of the titrations are given in Table VI. Some characteristic titration curves are shown in Figs. 3-5.

The results of the calculations are summarized in Table VII.

TABLE VII

p $K_{\mathrm{a}}$ VALUES IN 1,2-DICHLOROETHANE

\begin{tabular}{|c|c|}
\hline Compound & $p K_{u}$ \\
\hline $\begin{array}{l}\text { Trifluoromethanesulfonic acid } \\
\text { Hydriodic acid } \\
\text { Hydrobromic acid } \\
\text { Hydrochloric acid } \\
\text { Benzenesulfonic acid } \\
\text { Bromocresol green (1) } \\
\text { Picric acid } \\
\text { Bromochlorophenol blue (1) } \\
\text { Bromophenol blue (1) } \\
\text { Bromocresol purple (1) } \\
\text { Iodoacetic acid } \\
\text { Benzoic acid } \\
\text { Bromocresol green (2) } \\
\text { Bromochlorophenol blue (2) } \\
\text { Bromophenol blue (2) } \\
\text { Bromocresol purple (2) } \\
\text { Morpholine } \mathrm{H}^{+} \\
\text {Strychnine } \mathrm{H}^{+} \\
\text {"-Butylamine } \mathrm{H}^{+} \\
\text {Triethylamine } \mathrm{H}^{+} \\
\text {Tetramethylguanidine } \mathrm{H}^{+}\end{array}$ & $\begin{array}{r}7.3 \\
7.9 \\
8.7 \\
10.8 \\
12.1 \\
13.1 \\
13.7 \\
13.6 \\
14.8 \\
15.0 \\
17.6 \\
20.0 \\
22.2 \\
20.8 \\
23.8 \\
24.7 \\
15.0 \\
16.0 \\
17.0 \\
17.7 \\
21.5\end{array}$ \\
\hline
\end{tabular}

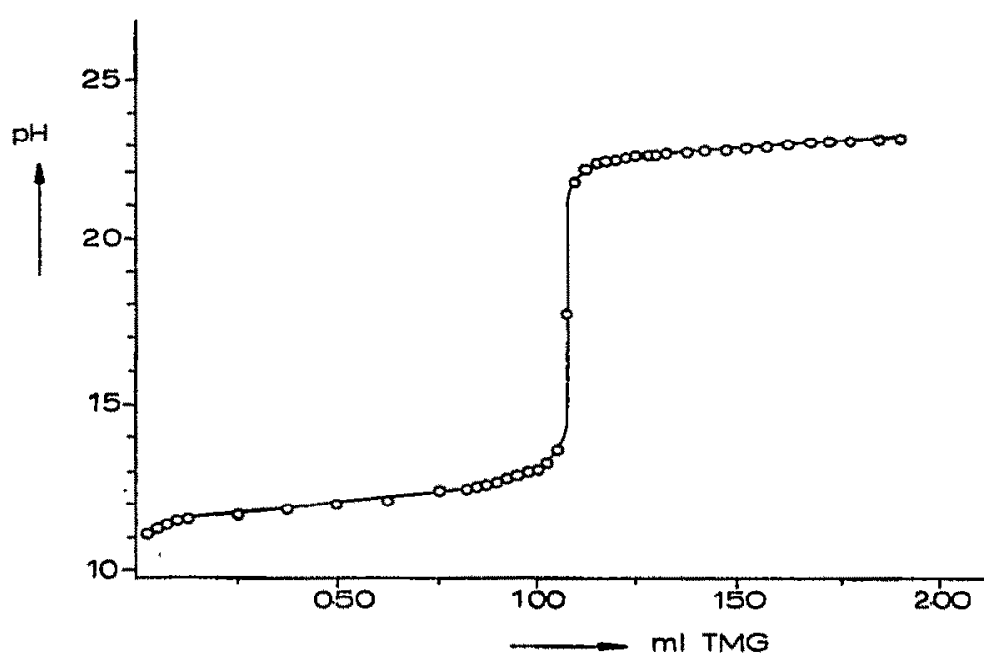

Fig. 3. Titration of $3 \mathrm{ml}$ of $0.03924 M$ picric acid with $0.1098 M$ TMG in dichloroethanc. (O) Experimental; $(\longrightarrow)$ curve calculated with $K_{d}^{11 x}=2 \cdot 10^{-14}, K_{r}^{n i t}=4 \cdot 10^{21}, K_{d}^{B H X}=10^{-5}$. 


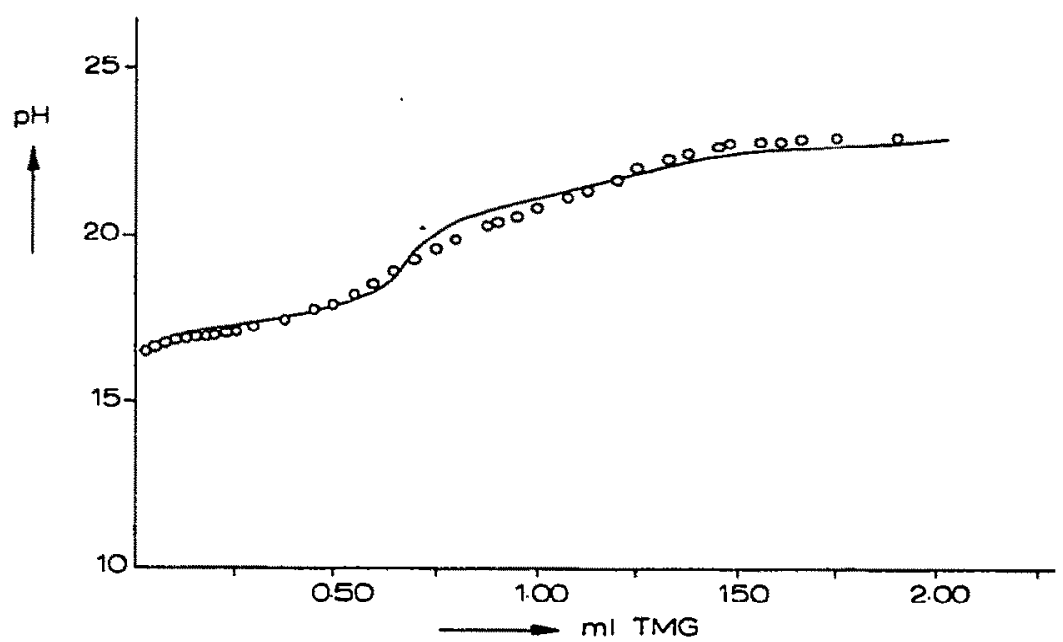

Fig. 4. Titration of $3 \mathrm{ml}$ of $0.04737 M$ benzoic acid with $0.1069 M$ TMG in dichloroethane. (O) Experimental ;

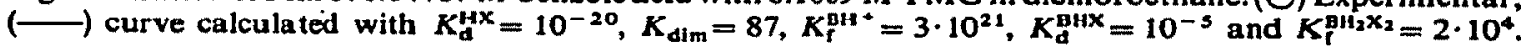

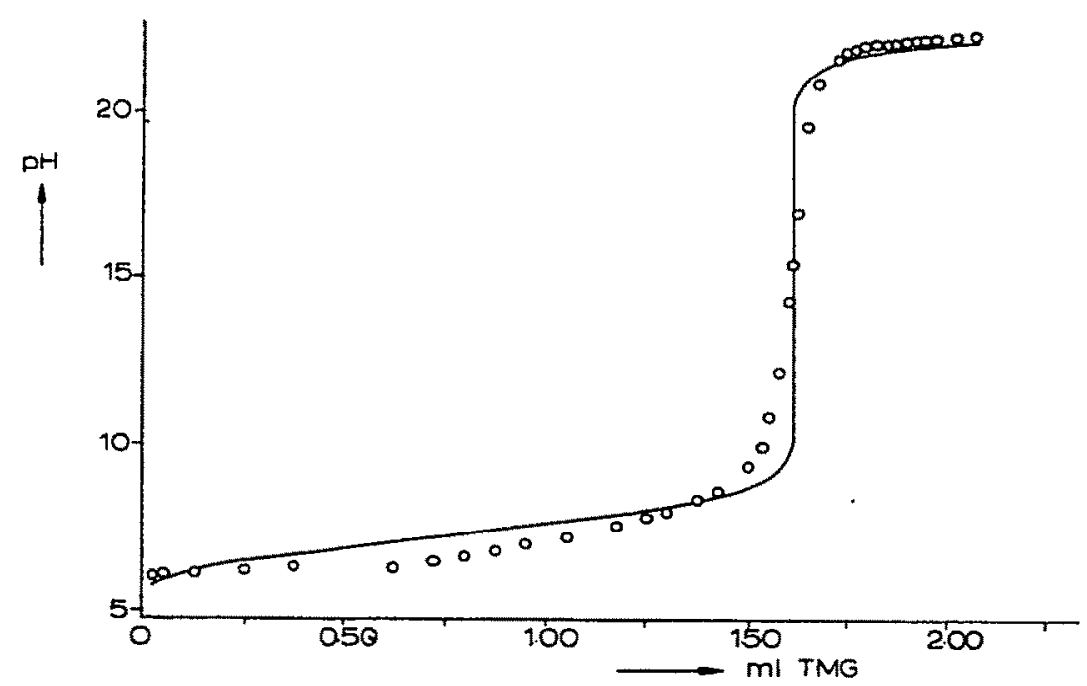

Fig. 5. Titration of $4 \mathrm{ml}$ of $0.0312 M$ hydrobromic acid with $0.0774 M T M G$ in dichloroethane. (O) Experimental; $(\longrightarrow)$ curve calculated with $K_{d}^{H X}=2 \cdot 10^{-9}, K_{f}^{\mathrm{gH}}=1.25 \cdot 10^{21}, K_{\mathrm{dHX}}^{\mathrm{BH}}=1.5 \cdot 10^{-3}$ and $K_{\mathrm{f}}^{\mathrm{BH} \mathrm{H}_{2}}=10^{2}$

\section{DISCUSSION}

Except for the formation of the complex $\mathrm{B}(\mathrm{HX})_{2}$ in the titrations of carboxylic acids with TMG, homoconjugation, i.e.

$$
\mathrm{HX}+\mathrm{X}^{-} \leftrightharpoons \mathrm{HX}_{2}^{-}
$$

could also explain the occurrence of the inflection point at the half-neutralization 
point. However, the homoconjugation constants necessary to give identical calculated and experimental titration curves are of an unreasonably high value. Moreover, homoconjugation does not give a calculated curve that fits the experimental curve exactly over the entire range. Therefore it must be accepted that the formation of $\mathbf{B}(\mathrm{HX})_{2}$ occurs.

The entire set of $\mathrm{p} K_{\mathrm{a}}$ values given in Table VII is based on the $\mathrm{p} K_{\mathrm{a}}$ value of hydriodic acid which was determined from conductivity measurements, by means of Walden's rule. Walden's rule is known to be an approximation, since ionic radii are not constant on transferring from one solvent to another. From Table II it can be seen that this rule holds roughly within a factor of 2 for the solvents $m$-cresol and dichloroethane. This implies that the $\mathrm{p} K_{\mathrm{n}}$ values given will not be more accurate than $\pm 1 \mathrm{p} K$ units.

The authors thank Miss Maasse-v.d. Brink for experimental help and Mrs. A. L. den Herder for preparing the manuscript.

\section{SUMMARY}

The $\mathrm{pK}_{\mathrm{a}}$ value of hydriodic acid in 1,2-dichloroethane was determined from conductivity measurements. A glass electrode was calibrated for dichloroethane in the potentiometric titration of hydriodic acid with tetramethylguanidine. From potentiometric titrations, the $\mathrm{p} K_{\mathrm{a}}$ values in dichloroethane of hydrobromic acid, hydrochloric acid, picric acid and some sulfonphthaleins as well as some protonated nitrogen bases were determined. In the curves of the titrations of the carboxylic acids and the hydrogen halides with $T M G$, evidence was found for the formation of the complex $\mathrm{B}(\mathrm{HX})_{2}$.

\section{RÉSUMÉ}

Des mesures de conductivité soṇt effectuées pour déterminer la valeur $\mathrm{p} K_{\mathrm{a}}$ de l'acide iodhydrique dans le dichloro-1,2-éthane. On étalonne une électrode de verre pour le dichloroéthane lors du titrage potentiométrique de l'acide iodhydrique par la tétraméthylguanidine. On a pu ainsi déterminer potentiométriquement les valeurs $\mathrm{p} K_{\mathrm{a}}$ dans le dichloroéthane des acides bromhydrique, chlorhydrique, picrique et de quelques sulfophtaléines. Les courbes de titrage des acides carboxyliques et halogénhydriques avec la tétraméthylguanidine indiquent la formation du complexe $B(H X)_{2}$ :

\section{ZUSAMMENFASSUNG}

Die $\mathrm{p} K_{\mathrm{a}}$-Werte von Jodwasserstoffsäure in 1,2-Dichloräthan wurden aus Leitfähigkeitsmessungen bestimmt. Eine Glaselektrode wurde für Dichloräthan bei der potentiometrischen Titration von Jodwasserstoffsäure mit Tetramethylguanidin (TMG) geeicht. Aus den potentiometrischen Titrationen wurden die $p K_{\mathrm{a}}-$ Werte in Dichloräthan von Bromwasserstoffsäure, Salzsäure, Pikrinsäure und einigen Sulfonphthaleinen ebenso wie von einigen protonierten Stickstoffbasen erimittelt. Die bei der Titration der Carbonsäuren und Halogenwasserstoffe mit TMG erhaltenen Kurven wiesen auf die Bildung des Komplexes $\mathrm{B}(\mathrm{HX})_{2}$ hin. 


\section{REFERENCES}

1 H. K. Hall, Jr., J. Phys. Chem. 60 (1956) 63.

2 Landolt-Börnstein, Zahlemwerte und Funktionen, 11 Band, 6. Teil, Springer Verlag, 1959, p. 625.

3 M. Bos and E. A. M. F. Dahmen, Anal. Chim. Acta: 57 (1971) 361.

4 M. Bos and E. A. M. F. Dahmen, Anal. Chim. Acta. 53 (1971) 39.

5 M. Bos and E. A. M. F. Dahmen, Anal. Chim. Acta, 55 (1971) 285.

6 R. M. Fuoss, J. Amer. Chem. Soc., 57 (1935) 488.

7 R. M. Fuoss and C. A. Kraus, J. Amer. Chem. Soc., 55 (1933) 476.

8 P. Walden, Z. Phys. Chem., 55 (1906) 207.

9 M. Bos and H. Q. J. Meershoek, Anal. Chim. Acta, in press.

10 J. F. Coetzee and Rose Mei-Shun Lok, J. Phys. Chem., 69 (1965) 2690. 